\title{
Second-crop cowpea under residual phosphorus doses in the Brazilian Amazon ${ }^{1}$
}

\author{
Rubson da Costa Leite ${ }^{2}$, Robson da Costa Leite ${ }^{2}$, Manoel da Silva Cravo ${ }^{3}$
}

\begin{abstract}
The southeastern mesoregion of the Brazilian Pará state is an important soybean producer, and the second-crop system can increase the local agricultural production. However, Latosols with medium to very clayey texture predominate in the region and, despite being suitable for farming, they naturally have low levels of available phosphorus (P). This study aimed to evaluate the yield of second-crop cowpea [Vigna unguiculata (L.) Walp] under doses of residual $\mathrm{P}$ in a Yellow-Latosol. Two experiments were installed under field conditions. The experimental design was randomized blocks, with five treatments (residuals of 0,50 , 100,150 and $200 \mathrm{~kg} \mathrm{ha}^{-1}$ of $\mathrm{P}_{2} \mathrm{O}_{5}$ ) and four replications. The first experiment consisted of cultivating second-crop cowpea after the soybean harvest, with phosphate doses provided during the soybean planting, and the second of second-crop cowpea after the rice harvest, with phosphate doses provided during the rice planting. The 1,000-grain weight and production of pods, husks and grains were evaluated. The production of pods and husks were higher in the area with residual $\mathrm{P}$. The highest yield was obtained in the residual dose of $200 \mathrm{~kg} \mathrm{ha}^{-1}$ of $\mathrm{P}_{2} \mathrm{O}_{5}$, reaching a grain yield of $1,256 \mathrm{~kg} \mathrm{ha}^{-1}$ after the soybean harvest and $885 \mathrm{~kg} \mathrm{ha}^{-1}$ after the rice harvest.
\end{abstract}

KEYWORDS: Vigna unguiculata (L.) Walp., Latosol, residual phosphorus.

\section{INTRODUCTION}

The estimated area planted with grains in Brazil, in 2020, is 61.5 million hectares, with an expected yield of around 241.4 million tons (Conab 2020). Among the grains produced in the country, cowpea (Vigna unguiculata L.) is of great importance, as it is a crop with relevance to food and nutritional security, being the main source of protein for millions of people in developing countries (Gonçalves et al. 2016, Lonardi et al. 2019).

\section{RESUMO}

Safrinha de feijão-caupi sob doses residuais de fósforo na Amazônia brasileira

A mesorregião sudeste paraense é importante produtora de soja, e o cultivo em safrinha pode incrementar a produção agrícola local. No entanto, na região, predominam Latossolos de textura média a muito argilosa, os quais, apesar de adequados ao uso agrícola, possuem, naturalmente, baixos níveis de fósforo disponível. Objetivou-se avaliar a produtividade de feijão-caupi [Vigna unguiculata (L.) Walp] em safrinha sob doses de fósforo residual em Latossolo Amarelo. Foram instalados dois experimentos em condições de campo. O delineamento experimental foi em blocos casualizados, com 5 tratamentos (residuais de 0, 50, 100, 150 e $200 \mathrm{~kg} \mathrm{ha}^{-1}$ de $\mathrm{P}_{2} \mathrm{O}_{5}$ ) e 4 repetições. O primeiro experimento consistiu de cultivo de feijão-caupi em safrinha após a safra da soja, com as doses fosfatadas fornecidas durante o plantio da soja, e o segundo de feijão-caupi em safrinha após a safra do arroz, com as doses fosfatadas fornecidas durante o plantio do arroz. Avaliaram-se o peso de mil grãos e produção de vagens, cascas e grãos. Houve maior produção de vagens e cascas em área com residual de fósforo. A maior produtividade foi obtida no residual da dose de $200 \mathrm{~kg} \mathrm{ha}^{-1}$ de $\mathrm{P}_{2} \mathrm{O}_{5}$, atingindo-se produtividades de grãos de $1.256 \mathrm{~kg} \mathrm{ha}^{-1}$ após a safra da soja e $885 \mathrm{~kg} \mathrm{ha}^{-1}$ após a safra do arroz.

PALAVRAS-CHAVE: Vigna unguiculata (L.) Walp., Latossolo, fósforo residual.

Cowpea is one of the main foods found on the table of Brazilians from the North and Northeast regions of the country (Melo et al. 2018). In the Pará state, it is highlighted in the productive scenario, especially in the northeastern mesoregion of the state, accounting for $45 \%$ of the total production in the state (Moreira et al. 2017).

In the last years, the production of cowpea in the Pará state has undergone significant socioeconomic changes, no longer being a subsistence-only crop, but assuming an important role in the state agribusiness

\footnotetext{
${ }^{1}$ Received: Oct. 09, 2020. Accepted: Nov. 26, 2020. Published: Dec. 16, 2020. DOI: 10.1590/1983-40632020v5066078.

${ }^{2}$ Universidade Federal Rural da Amazônia, Instituto de Ciências Agrárias, Belém, PA, Brasil.

E-mail/ORCID: rubsonif@gmail.com/0000-0002-3572-7600, robsontec.agrop@gmail.com/0000-0002-7231-942X.

${ }^{3}$ Empresa Brasileira de Pesquisa Agropecuária (Embrapa Amazônia Oriental), Belém, PA, Brasil. (In memoriam)
} 
(Rodrigues et al. 2020). On the other hand, the southeastern region of Pará has become an important producer of soybean and corn; but, because of the prevailing climate in the region (Awi, according to the Köppen classification), farmers still do not have a defined crop for growing as a second crop (Bastos et al. 2005). In this case, because it is a short-cycle crop, cowpea can be an important alternative for corn and soybean producers in southeastern Pará, for cultivation as a second crop, in which it can be planted after harvesting these crops, using the end of the rainy season, as it has already been successfully practiced by the soybean farmers of the Brazilian Mato Grosso state (Rodrigues et al. 2020).

In Paragominas and other cities in the southeastern region of the Pará state, where the soybean and corn crops are expanding, Oxisols with medium to very clayey textures are predominant (IBGE 2008), which, although suitable for farming, are acidic and have low natural fertility, in which phosphorus $(\mathrm{P})$ is one of the most limiting elements (Rodrigues et al. 2003). On the other hand, cowpea has shown frequent responses to P (Smyth \& Cravo 1990a) and the low availability of this element in the soil negatively affects the plant growth and, consequently, yield (Smyth \& Cravo 1990b, Silva et al. 2019a).

Correcting the fertility of these soils has provided good soybean and corn yields. Also, residues of the phosphate fertilizers applied to these crops, depending on the applied dose, may maintain high levels of $\mathrm{P}$ in the soil after harvest, which may be sufficient for a second crop. Thus, this study aimed to evaluate the performance of cowpea as a second crop, after soybean or rice cultivation, using only the residual $\mathrm{P}$ from previous crops, in a very clayey Yellow Latosol.

\section{MATERIAL AND METHODS}

Two field experiments were carried out in Paragominas (Figure 1), Pará state, Brazil, in 2018 and 2019. The climate in the region is classified as "Awi", according to the Köppen classification (Alvares et al. 2013), and the soil in the experimental areas as a very clayey Yellow Latosol, which corresponds to an Oxisol (USDA 2014), whose physical-chemical attributes are shown in Table 1 (Embrapa 2018). The levels of $\mathrm{P}$ in the soil (collected by sampling in all experimental areas), after the soybean and rice harvest (crops that preceded the cowpea cultivation), are shown in Table 2.

The experimental design was randomized blocks, with five treatments (residuals of $0,50,100$, 150 and $200 \mathrm{~kg} \mathrm{ha}^{-1}$ of $\mathrm{P}_{2} \mathrm{O}_{5}$ ) and four replications. The first experiment was second-crop cowpea cultivation after the soybean harvest, in which the P doses $(0$, $50,100,150$ and $200 \mathrm{~kg} \mathrm{ha}^{-1}$ of $\mathrm{P}_{2} \mathrm{O}_{5}$ ) were provided

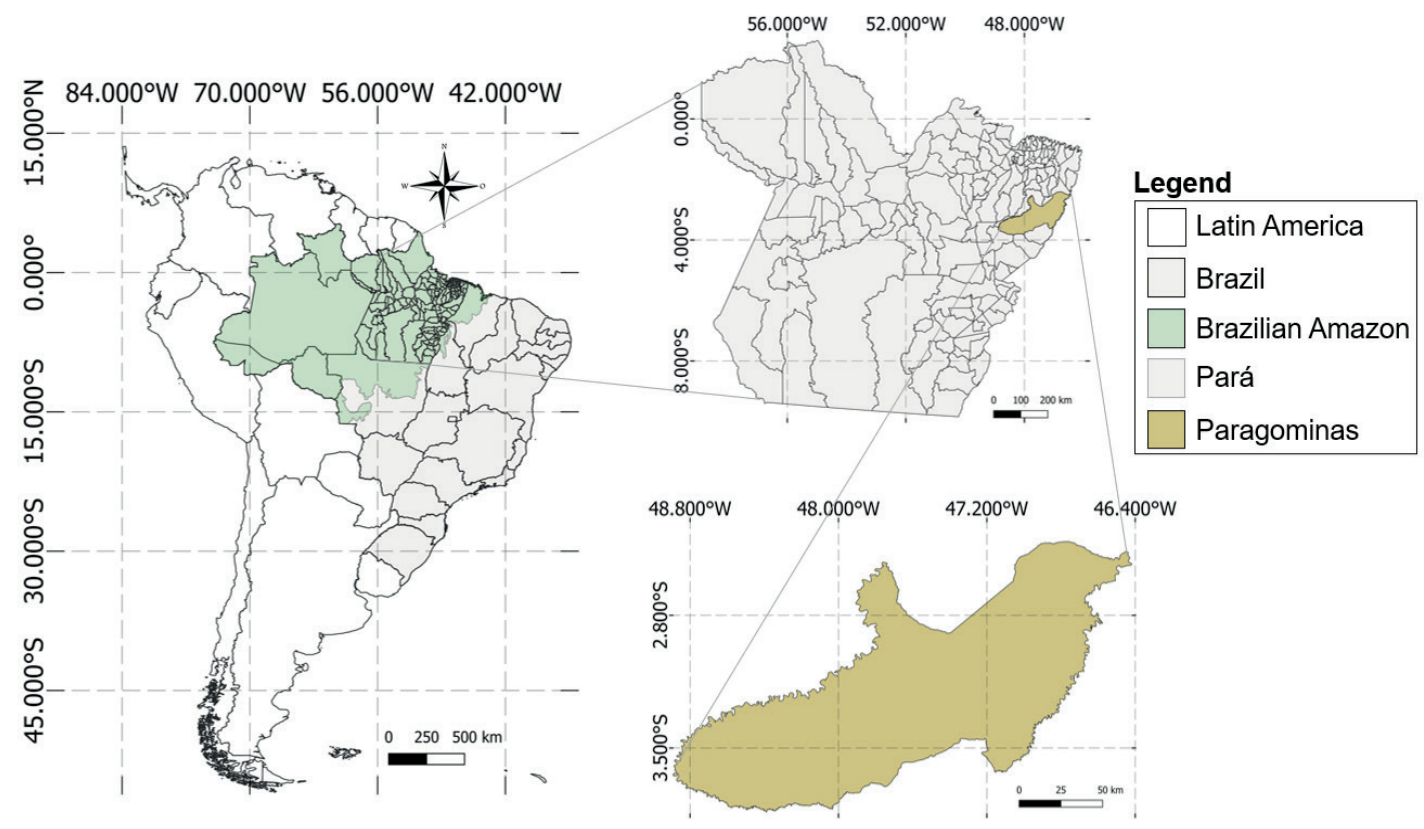

Figure 1. Experimental area location. 
Table 1. Soil physical and chemical attributes (0-20 $\mathrm{cm}$ layer) of the experimental area before planting and harvesting fertilization.

\begin{tabular}{|c|c|c|}
\hline Parameter & Soybean & Rice \\
\hline $\mathrm{pH}\left(\mathrm{CaCl}_{2}\right)$ & 5.1 & 5.20 \\
\hline Organic matter $\left(\mathrm{g} \mathrm{kg}^{-1}\right)$ & 3.1 & 3.00 \\
\hline Phosphorus (mg kg-1) & 2.3 & 3.90 \\
\hline Potassium (mg kg-1) & 101.0 & 157.00 \\
\hline Calcium $\left(\mathrm{cmol}_{\mathrm{c}} \mathrm{kg}^{-1}\right)$ & 3.4 & 4.50 \\
\hline Magnesium $\left(\mathrm{cmol}_{\mathrm{c}} \mathrm{kg}^{-1}\right)$ & 1.2 & 1.48 \\
\hline Aluminium $\left(\mathrm{cmol}_{\mathrm{c}} \mathrm{kg}^{-1}\right)$ & 0.2 & 0.08 \\
\hline $\mathrm{H}+\mathrm{Al}\left(\mathrm{cmol}_{\mathrm{c}} \mathrm{kg}^{-1}\right)$ & 3.0 & 2.80 \\
\hline Sum of bases $\left(\mathrm{cmol}_{\mathrm{c}} \mathrm{kg}^{-1}\right)$ & 4.8 & 6.40 \\
\hline Cation exchange capacity $\left(\mathrm{cmol}_{\mathrm{c}} \mathrm{kg}^{-1}\right)$ & 7.8 & 9.20 \\
\hline $\mathrm{V}(\%)$ & 61.0 & 69.00 \\
\hline Sand $(\%)$ & 10.5 & 12.00 \\
\hline Silt (\%) & 5.0 & 6.40 \\
\hline Clay $(\%)$ & 84.5 & 81.60 \\
\hline
\end{tabular}

Available $\mathrm{P}$ and $\mathrm{K}$ : Mehlich-1 extraction; exchangeable $\mathrm{Ca}, \mathrm{Mg}$ and $\mathrm{Al}: \mathrm{KCl}$ extraction; $\mathrm{H}+\mathrm{Al}$ : calcium acetate extraction.

Table 2. Phosphorus (P) contents existing in the soil after the crop harvest.

\begin{tabular}{ccc}
\hline $\begin{array}{c}\text { Applied } \mathrm{P} \\
\left(\mathrm{kg} \mathrm{ha}^{-1} \text { of } \mathrm{P}_{2} \mathrm{O}_{5}\right)\end{array}$ & Soil $\mathrm{P}$ content $\left(\mathrm{mg} \mathrm{dm}^{-3}\right)-$ & Rice \\
\hline 0 & 2.3 & 3.9 \\
50 & 9.0 & 8.0 \\
100 & 28.5 & 11.9 \\
150 & 31.8 & 22.0 \\
200 & 33.3 & 23.0 \\
\hline $\mathrm{MSD}(0.05)$ & 14.8 & 5.1 \\
\hline $\mathrm{CV}(\%)$ & 45.9 & 24.0 \\
\hline
\end{tabular}

MSD: minimum significant difference; $\mathrm{CV}$ : coefficient of variation.

during the soybean planting. The experimental units consisted of one area of $40 \mathrm{~m}^{2}(10$ lines of $8.0 \mathrm{~m}$, spaced in $0.5 \mathrm{~m})$ and one useful area of $24 \mathrm{~m}^{2}(6$ lines of $4.0 \mathrm{~m}$, central). The cowpea BR3 Tracuateua cultivar was used. In the second experiment, the Novaera cultivar was used as a second crop, after the rice harvest, with $\mathrm{P}$ doses $(0,50,100,150$ and 200 $\mathrm{kg} \mathrm{ha}^{-1}$ of $\mathrm{P}_{2} \mathrm{O}_{5}$ ) provided during the rice planting. In both the cowpea cultivations, fertilization consisted only of potassium supplementation (broadcast fertilization), as recommended for the crop (Cravo et al. 2010). The experimental units consisted of one area of $30 \mathrm{~m}^{2}$ (10 lines of $6.0 \mathrm{~m}$, spaced in $\left.0.5 \mathrm{~m}\right)$ and one useful area of $18 \mathrm{~m}^{2}$ (6 lines of $3.0 \mathrm{~m}$, central).

At the end of the cowpea cycle, the pods of each plot were harvested and the humidity adjusted to $13 \%$ (with the aid of an oven). Subsequently, these pods were weighed and their values adjusted to $\mathrm{kg} \mathrm{ha}^{-1}$, thus obtaining the pod yield values. After weighing the pods, the components husks and grains were separated and weighed individually. For the 1,000-grain weight, the grains were manually counted (humidity of $13 \%$ ) and subsequently weighed.

Initially, the data were tested for normality (Shapiro \& Wilk) and homoscedasticity (Levene). Next, the data were subjected to regression analysis, evaluating the significance of the betas and the coefficients of determination, to obtain the appropriate model and subsequently the response curve. The graphs were produced using the SigmaPlot ${ }^{\mathrm{TM}} 10$ software.

\section{RESULTS AND DISCUSSION}

In the two cultivation years, a relationship between yield and phosphate fertilizer doses was observed (Figure 2). For the first year of evaluation (2018), only the variable 1,000-grain weight did not adjust to the proposed regression model.

The pod production was adjusted to the linear regression model (Figure 2A). The maximum response for pod production, as a function of the phosphate fertilizer, occurred in the residual dose of $200 \mathrm{~kg} \mathrm{ha}^{-1}$ of $\mathrm{P}_{2} \mathrm{O}_{5}$, reaching $1,760 \mathrm{~kg} \mathrm{ha}^{-1}$. Considering the non-application of phosphate fertilizer, the pod yield was $207 \mathrm{~kg} \mathrm{ha}^{-1}$, with an increase of $7.7 \mathrm{~kg}$ in the production of pods for each $\mathrm{kg}$ of $\mathrm{P}_{2} \mathrm{O}_{5}$ applied (Figure 2A). For the husk production, a similar behavior was observed, with a maximum response at the dose of $200 \mathrm{~kg} \mathrm{ha}^{-1}$ of phosphate fertilizer: $420 \mathrm{~kg} \mathrm{ha}^{-1}$ (Figure 2B). When phosphate fertilizer was not applied, the husk production was only $54 \mathrm{~kg} \mathrm{ha}^{-1}$, with an increase of $1.8 \mathrm{~kg}$ for each $\mathrm{kg}$ of $\mathrm{P}_{2} \mathrm{O}_{5}$ applied.

The husk production was quite high with the increase in the phosphate fertilization (Figure 2B), what was already expected, since the application of $\mathrm{P}$ in a bean crop promotes, among other benefits, an increase in the production of shoot dry matter (Oliveira et al. 2011). Cowpea is of great importance for the diet and food security of a large part of the population of Pará, but the reduction in the cropped area and yield, in recent years, in the major region of the state (northeastern Pará) (Moreira et al. 2017), may bring problems to the population, especially the low-income one. This reinforces the importance of second-crop cultivation, given the good results found in this study, constituting a viable alternative that 


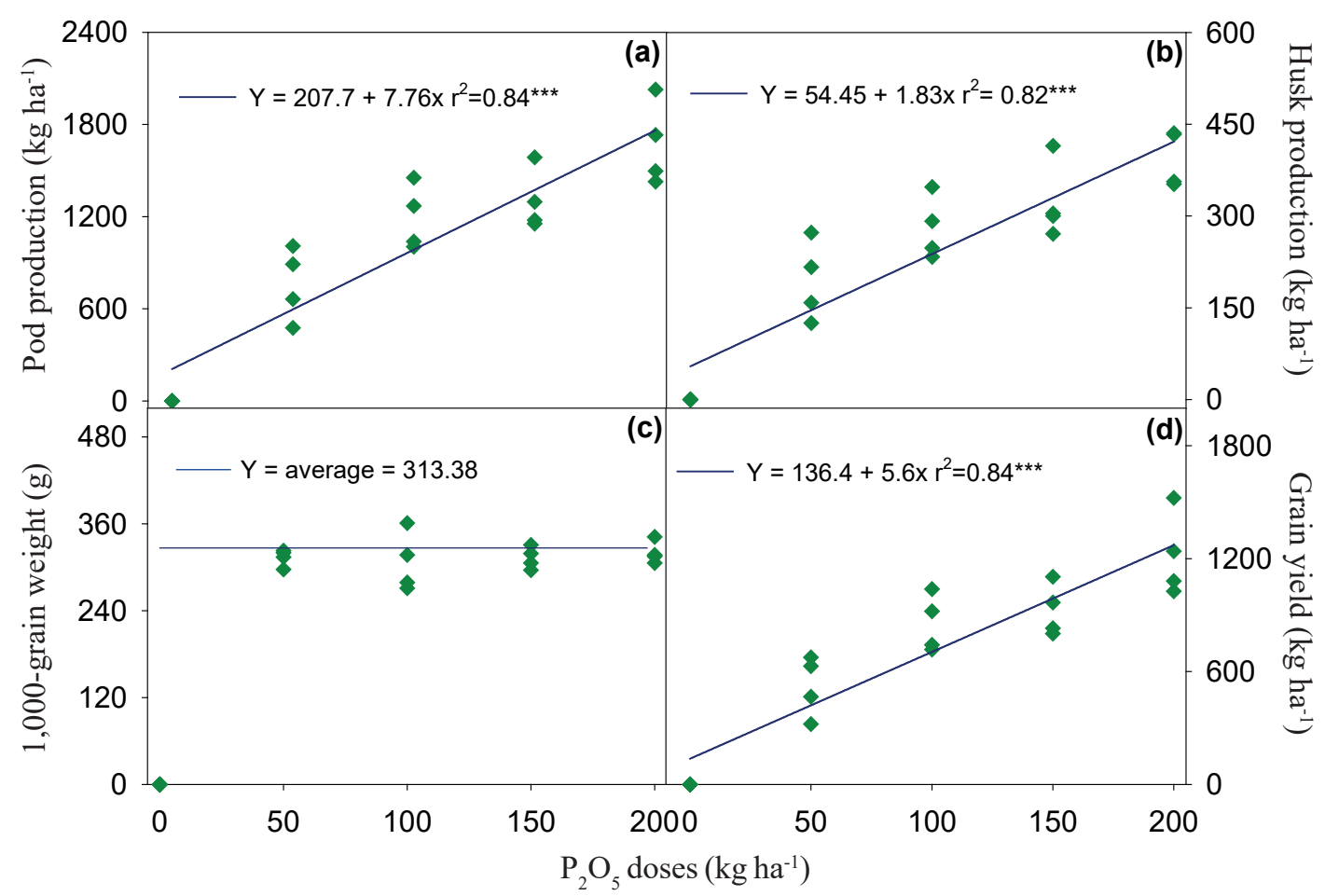

Figure 2. Pod production (A), husk production (B), 1,000-grain weight (C) and grain yield (D) of cowpea (Vigna unguiculata L.) under fertilization of soybean-crop residual phosphate doses.

can increase the cowpea production in the state and reduce the production costs of the soybean and corn crops in the region.

The 1,000-grain weight showed an average of $313 \mathrm{~g}$ for each 1,000 grains, regardless of the applied dose of $\mathrm{P}$ (Figure 2C). However, in the absence of phosphate fertilization, similarly to all the variables analyzed in the first year, the values were low and the pods and grains were of poor quality.

The low 1,000-grain weight may have occurred due to the low availability of $\mathrm{P}$, reducing the grains weight (Fancelli \& Dourado Neto 2007). Due to the short cycle between planting and harvesting, as well as the low volume of soil explored by the bean roots, the low availability of nutrients in the soil is one of the main factors limiting the yield of this crop (Silva et al. 2019a). There is also the fact that $P$ is demanded throughout the vegetative cycle, until the bean maturation, what allows the adequate functioning of the carbohydrate translocation mechanism, so that there is no reduction in yield (Grant et al. 2001).

Similarly to the results obtained in this study, Silva et al. (2019b) found no significant difference for the 1,000-grain weight, as a function of the applied fertilization, except in the treatment that did not receive fertilization. For common bean, Oliveira et al. (2011) mention studies in which the 1,000-grain weight of bean showed lower values in the treatment without P supply, and, for the other doses, there was no significant difference.

Since there was no significant difference in the 1,000-grain weight in the plants that received phosphate fertilizer (Figure 2C), a difference was observed in the total production of pods and grains (Figures 2A and 2D). In addition, the number of grains and formed pods contributed to an increase in the yield of the second-crop cowpea.

The grain yield obtained in the experiment was adjusted to the linear regression model (Figure 2D). The maximum grain yield was $1,256 \mathrm{~kg} \mathrm{ha}^{-1}$, which was reached with the residual application of $200 \mathrm{~kg} \mathrm{ha}^{-1}$ of $\mathrm{P}_{2} \mathrm{O}_{5}$. At the zero dose of phosphate fertilizer, the grain yield was $136 \mathrm{~kg} \mathrm{ha}^{-1}$, with an increase of $5.6 \mathrm{~kg}$ of grains for each $\mathrm{kg}$ of $\mathrm{P}_{2} \mathrm{O}_{5}$ applied.

The national average for cowpea yield is around $665 \mathrm{~kg} \mathrm{ha}^{-1}$ (Conab 2020). In this studied region, the yields reached twice the grain yield of the national average (Figures 2D and 3B). Considering the average of $1,200 \mathrm{~kg} \mathrm{ha}^{-1}$ in the Mato Grosso state, for the 2020 harvest, a similar result was obtained in 


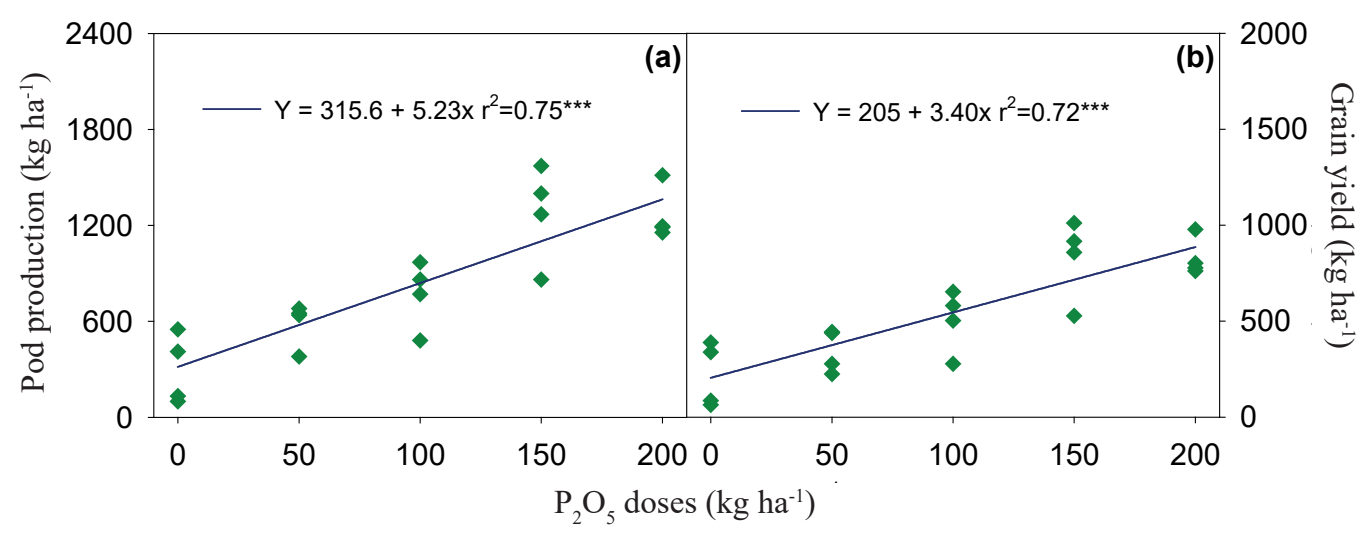

Figure 3. Pod production (A) and grain yield (B) of cowpea (Vigna unguiculata L.) plants under rice-crop residual phosphorus fertilizer.

this study region, in the first year of the experiment. In the second year, after rice cultivation, similarly to that conducted in an area after soybean cultivation, the cowpea plants achieved the highest yield in the residual of the highest dose of phosphate fertilizer (Figure 3).

Even though the evaluated doses of $\mathrm{P}$ were applied during the planting of soybean and rice crops, the cowpea had an increasing response to $\mathrm{P}$, due to the increase in the evaluated doses (Figures 2 and 3). The $P$ residual effect is dependent on the dose and source solubility, so the use of the applied $\mathrm{P}$ represents the percentage of $\mathrm{P}$ that was not absorbed by the previous crop (Ramos et al. 2010). Thus, part of the P applied to the main crops remained in the soil of the area, in addition to a large part extracted that returned to the soil with the crop residues of soybean and rice, since only the grains were exported.

The pod production was adjusted to the linear model, observing that, in the absence of phosphate fertilizer, the yield was $315 \mathrm{~kg} \mathrm{ha}^{-1}$, with an increase of $5.23 \mathrm{~kg} \mathrm{ha}^{-1}$ for each $\mathrm{kg}$ of $\mathrm{P}_{2} \mathrm{O}_{5}$ applied, reaching the highest yield of $1,361 \mathrm{~kg} \mathrm{ha}^{-1}$ in the residual of $200 \mathrm{~kg} \mathrm{ha}^{-1}$ of $\mathrm{P}_{2} \mathrm{O}_{5}$ (Figure 3A).

The pod production in the second-crop cowpea following the soybean crop increased by up to 8 times, if compared to plants that did not receive phosphate fertilization (Figure 2A). For the secondcrop cowpea plants followed by rice cultivation, the pod production was up to 4 times higher than that of the cultivated plants to which there was no application of residual P (Figure 3A). This can be explained by the fact that, among its benefits, $\mathrm{P}$ increases the number of pods and the mass of grains (Fageria et al. 2003). In addition, $\mathrm{P}$ is one of the nutrients that most limits the cowpea production, considering the soil conditions and properties of the element in the medium (Fernandes et al. 2013).

The cowpea grain yield showed an adjustment to the linear model (Figure 3B), where, in the absence of phosphate fertilizer application, the yield was $205 \mathrm{~kg} \mathrm{ha}^{-1}$, with an increase of $3.4 \mathrm{~kg}$ for each $\mathrm{kg}$ of $\mathrm{P}_{2} \mathrm{O}_{5}$ applied, with a maximum yield of $885 \mathrm{~kg} \mathrm{ha}^{-1}$ in the residual dose of $200 \mathrm{~kg} \mathrm{ha}^{-1}$ of $\mathrm{P}_{2} \mathrm{O}_{5}$.

The adequate nutrient supply made by the crop fertilization is crucial for high yields, but this increases the production costs. For this reason, the evaluation of the residual effect of the applied fertilizers is important to minimize the crop costs (Bezerra et al. 2014).

The Mato Grosso state is considered the largest soybean producer in the country, and, to optimize the adopted resources using the fertilizer residues from the previous crop, a commonly used practice is the cultivation of second-crop cowpea (Menezes Júnior et al. 2019), with a high yield and low production cost, since only the weed control and complementary fertilization, mainly potash (Cravo et al. 2009), are needed. Based on the results obtained in this study, for the southeastern region of Pará, this practice could also be adopted in the region, resulting in high cowpea yields with a low investment, since it is a leguminous species that may have part of the nitrogen necessary for its nutrition through the biological fixation of atmospheric nitrogen $\left(\mathrm{N}_{2}\right)$, in addition to using $\mathrm{P}$ residues applied in the soybean planting.

Although the P content in the soil was above the critical level established for cowpea in a soil similar to that of the present study (Smyth \& Cravo 1990a), the results for pod, grain and husk production 
had a linear behavior, both in the first and second experiments (Figures 2 and 3). These results may be related to the efficiency of $\mathrm{P}$ absorption by the crops and the $\mathrm{P}$ adsorption capacity (Zucareli et al. 2010), because this soil has a very clayey texture, with more than $80 \%$ of clay on the A horizon (Table 1). According to Novais \& Smyth (1999), among the soil attributes that most influence the P adsorption, the clay content stands out.

In addition, according to Zucareli et al. (2010), the efficiency in phosphate fertilization is considered low in clayey soils, as a large part of the element added to the soil becomes immobile or unavailable to the crops because of the adsorption reactions in mineral colloids, precipitation or conversion to organic forms. Therefore, despite the large amounts of $\mathrm{P}$ applied to the soil and remaining after the soybean and rice harvests, only a part of this $\mathrm{P}$ was used for cultivating cowpea in a second crop, but with a very satisfactory grain yield, what makes this a very interesting practice for this soybean and corn producer pole in southeastern Pará, similarly to what has already been done in the Mato Grosso state.

\section{CONCLUSIONS}

1. The residual phosphorus applied to the main crop allowed to nourish the second-crop cowpea, thus obtaining good yields and constituting an alternative for the use of the applied inputs and with the possibility of improving the farmer's income;

2. The highest yield was obtained in the residual dose of $200 \mathrm{~kg} \mathrm{ha}^{-1}$ of $\mathrm{P}_{2} \mathrm{O}_{5}$, reaching grain yields of $1,256 \mathrm{~kg} \mathrm{ha}^{-1}$ after the soybean harvest and $885 \mathrm{~kg} \mathrm{ha}^{-1}$ after the rice harvest.

\section{REFERENCES}

ALVARES, C. A.; STAPE, J. L.; SENTELHAS, P. C.; GONÇALVES, J. L. D. M.; SPAROVEK, G. Köppen's climate classification map for brazil. Meteorologische Zeitschrift, v. 22, n. 6, p. 711-728, 2013.

BASTOS, T. X; PACHÊCO, N. A; FIGUEIRÊDO, R. O.; SILVA, G. F. G. Características agroclimáticas do municipio de Paragominas. Belém: Embrapa Amazônia Oriental, 2005. (Documentos, 228).

BEZERRA, M. A. F.; OLIVEIRA, F. A.; BEZERRA, F. T. C.; PEREIRA, W. E.; SILVA, S. A. Cultivo de feijão-caupi em Latossolos sob o efeito residual da adubação fosfatada. Revista Caatinga, v. 27, n. 1, p. 109-115, 2014.

COMPANHIA NACIONAL DE ABASTECIMENTO (Conab). Acompanhamento da safra brasileira de grãos: safra 2019/20. Disponível em: https://www.conab.gov.br/ info-agro/safras/graos/boletim-da-safra-de-graos. Acesso em: 15 dez. 2020.

CRAVO, M. S.; SOUZA, B. D. L.; CUNHA, F. D. R.; CAVALCANTE, E. S.; ALVES, J. M. A.; MARINHO, J. T. S.; VEIRA JÚNIOR, J. R.; GONÇALVES, J. R. P.; FREITAS, A. C. R.: TOMAZETTI, M. A. Sistema de cultivo. In: ZILLI, J. E.; VILARINHO, A. A.; ALVES, J. M. A. (ed.). A cultura do feijão-caupi na Amazônia brasileira. Boa Vista: Embrapa Roraima, 2009. p. 59-104.

CRAVO, M. S.; VIÉGAS, I. J. M.; BRASIL, E. C. (ed.). Recomendação de adubação e calagem para o estado do Pará. Belém: Embrapa Amazônia Oriental, 2010.

EMPRESA BRASILEIRA DE PESQUISA AGROPECUÁRIA (Embrapa). Sistema brasileiro de classificação de solos. 5. ed. Brasília, DF: Embrapa, 2018.

FAGERIA, N. K.; BARBOSA FILHO, M. P.; STONE, L. F. Resposta do feijoeiro a adubação fosfatada. Informações Agronômicas, n. 102, p. 1-9, 2003.

FANCELLI, A. L.; DOURADO NETO, D. Produção de feijão. Piracicaba: Agronômica Ceres, 2007.

FERNANDES, A. R.; FONSECA, M. R.; BRAZ, A. M. S. Produtividade de feijão caupi em função da calagem e fósforo. Revista Caatinga, v. 26, n. 4, p. 54-62, 2013.

GONÇALVES, A.; GOUFO, P.; BARROS, A.; DOMÍNGUEZ-PERLES, R.; TRINDADE, H.; ROSA, E. S.; FERREIRA, L.; RODRIGUES, M. Cowpea (Vigna unguiculata L.Walp), a renewed multipurpose crop for a more sustainable agri-food system: nutritional advantages and constraints. Journal of the Science of Food and Agriculture, v. 96, n. 9, p. 2941-2951, 2016.

GRANT, C. A.; FLATEN, D. N.; TOMASIEWICZ, D. J.; SHEPPARD, S. C. A importância do fósforo no desenvolvimento inicial da planta. Informações Agronômicas, n. 95, p. 1-5, 2001.

INSTITUTO BRASILEIRO DE GEOGRAFIA E ESTATÍSTICA(IBGE). Mapa de solos do estado do Pará. 2008. Disponível em: https://mapas.ibge.gov.br/tematicos/ solos. Acesso em: 01 fev. 2020.

LONARDI, S.; AMATRIAIN, M. M.; LIANG, Q.; SHU, $\mathrm{S}$. The genome of cowpea (Vigna unguiculata [L.] Walp.). The Plant Journal, v. 98, n. 5, p. 767-782, 2019.

MELO, A. S.; SILVA, A. R. F.; DUTRA, A. F.; DUTRA, W. F.; BRITO, M. E. B.; SÁ, F. V. S. Photosynthetic efficiency and production of cowpea cultivars under 
deficit irrigation. Revista Ambiente \& Água, v. 13, n. 5, e2133, 2018.

MENEZES JÚNIOR, J. A.; SILVA, K. J. D.; ROCHA, M. M.; FREIRE FILHO, F. R. A cultura do feijão-caupi em Mato Grosso. In: FARIAS NETO, A. L.; NASCIMENTO, A. F.; ROSSONI, A. L. Embrapa Agrossilvipastoril: primeiras contribuições para o desenvolvimento de uma agropecuária sustentável. Brasília, DF: Embrapa, 2019. p. 628-634.

MOREIRA, W. K. O.; OLIVEIRA, S. S.; ALVES, J. D. N.; RIBEIRO, R. A. R.; OLIVEIRA, I. A.; SOUSA, L. A. S. Evolução da produtividade do feijão-caupi para os principais produtores do nordeste paraense no período de 2000 a 2014. Nucleus, v. 14, n. 1, p. 341-351, 2017.

NOVAIS, F. R.; SMYTH, T. J. Fósforo em solo e planta em condições tropicais. Viçosa: Ed. UFV, 1999.

OLIVEIRA, G. A.; ARAÚJO, W. F.; CRUZ, P. L. S.; SILVA, W. L. M.; FERREIRA, G. B. Resposta do feijãocaupi as lâminas de irrigação e as doses de fósforo no Cerrado de Roraima. Revista Ciência Agronômica, v. 42, n. 4, p. 872-882, 2011.

RAMOS, S. J.; FAQUIN, V.; RODRIGUES, C. R.; SILVA, C. A. Efeito residual das aplicações de fontes de fósforo em gramíneas forrageiras sobre o cultivo sucessivo da soja em vasos. Bragantia, v. 69, n. 1, p. 149-155, 2010.

RODRIGUES, J. E. L. F.; FREIRE FILHO, F. R.; BOTELHO, S. M.; AZEVEDO, R.; RUSNY, J. C. E.; RODRIGUES, M. C. S. F.; OLIVEIRA, R. P.; MIRANDA JUNIOR, J. P.; CALZAVARA, B. B. Avaliação da produtividade de cultivares de feijão-caupi para cultivo no estado do Pará. Belém: Embrapa Amazônia Oriental, 2020.
RODRIGUES, T. E.; SILVA, R. C.; SILVA, J. M. L.; OLIVEIRA JÚNIOR, R. C.; GAMA, J. R. N. F.; VALENTE, M. A. Caracterização e classificação dos solos do município de Paragominas, estado do Pará. Belém: Embrapa Amazônia Oriental, 2003. (Documentos, 162).

SILVA, C. F.; MOURA, M. F.; VILELA, A. R. R.; ARAÚJO, M. B.; MARQUES, J. D. S. Produção de feijão-caupi em função do emprego de inoculante e adubos orgânicos e mineral. Diversitas Journal, v. 4, n. 3, p. 1130$1145,2019 b$.

SILVA, E. M.; SANTOS, M. M.; LOPES, M. B. S.; FIDELIS, R. R.; ROCHA, W. S.; CHAGAS JÚNIOR, A. F. Eficiência de rizóbios sob doses de fósforo na cultura do feijão-caupi. Revista Brasileira de Agropecuária Sustentável, v. 9, n. 2, p. 67-77, 2019a.

SMYTH, T. J.; CRAVO, M. S. Critical phosphorus levels for corn and cowpea in a Brazilian Amazon Oxisol. Agronomy Journal, v. 82, n. 2, p. 309-312, 1990a.

SMYTH, T. J.; CRAVO, M. S. Phosphorus management for continuous corn-cowpea production in a Brazilian Amazon Oxisol. Agronomy Journal, v. 82, n. 2, p. 305309, 1990b.

UNITED STATES DEPARTMENT OF AGRICULTURE (USDA). Soil Survey Staff. Keys to soil taxonomy. 12. ed. Washington, DC: USDA, 2014.

ZUCARELI, C.; RAMOS JUNIOR, E. U.; OLIVEIRA, M. A.; CAVARIANI, C.; NAKAGAWA, J. Índices biométricos e fisiológicos em feijoeiro sob diferentes doses de adubação fosfatada. Semina: Ciências Agrárias, v. 31, n. 1, p. 1313-1323, 2010. 